\title{
酸化亜鉛素子の急峻波特性に関する理論的検討
}

\author{
正員 小島宗次 学生員 江頭健太郎 正員 河野照哉 正員 錦織 康男 \\ (工学院大学)
}

\section{Theoretical Study of Performance to Very Fast Transients on Zinc Oxide Elements}

\section{Soji Kojima,Member Kentarou Egasira,Student Member Teruya Kouno,Member}

\begin{abstract}
Yasuo Nishikori ,Member (Kogakuin University)
Response characteristics of a $\mathrm{ZnO}$ element generally used for surge arresters against very fast transients are hardly known. They have not only non-linear resistance characteristics but also dielectric ones. We have developed an analytical digital program to study internal resistive and capacitive currents of the element to very fast transient current , based on Maxwell equations. And moreover,proposed equivalent circuit has been found to agree with the above theoretical method .

This paper shows not only good agreement of theoretical method and equivalent circuit, but also new phenomena of skin and Ferranti effects on $\mathrm{ZnO}$ internal currents.
\end{abstract}

キーワード：酸化重鉛形避雷器, 酸化重鉛素子, 周波数効果, 表皮効果, フェランチ効果

つた。

すなわち,内部電流分死に関して表皮効果だけではなく，

\section{1.まえがき}

酸化严鉛形避雷器は電力系統で広く適用されるに至って おり，系統に発生する各種の過電压に対する保護が期待さ れている。断路器開閉サージ，第一鉄塔落雷や多重雷に扔 ける後緢雷擊など非常に高周波の急峻なサージも存在する が，酸化亜鉛素子の急峻波に対する応答特性が末だ十分解 明されていない。

波頍長 $1 \mu \mathrm{s}(250 \mathrm{kHz}$ に対応)付近での避雷器のモデルの 研究結果は文献(1)(2)にも多数見られ, また筆者も以前研 究した結果をまとめているが(い，より急峻な $\mathrm{MHz}$ 級の電 流に関する応答はあまり今までに研究がなるれていないか， なされていても(4)初期の研究に止まっている。

このような急峻波店答を寒験的に行うとすると，急峻波 電流・電圧の発生や測定を精度良く行うことが極めて困難 な問題がある。

そこで本譣文では二つの独立した検討を行った。すなわ 古, 純理論的検討と等価回路に上る検討の雨者を行い, そ の結果がよく一致することを確認した。

また酸化亚鉛素子は非直線抵抗体であると同時に大きな 誘電率を有する誘電体でもあり，高周波になるほど誘電体 の特性を無視できなく傾向にある。一般的に金属や抵抗体 に対しては表皮効果が発生するが，上記のように複合誘電 体になると現象が一層複雑になることが解析結果より分か
フェランチ効果も存在するこ上が分かった。

本論文はいままで検討した結果(5)(6)(7)(8)㞭まとめ, 諸データを加えて総合的にした論文である。

\section{2. 理論的検討}

<2. $1>$ 関保式の導入 マックスウェルの方程式を一 般の物質に適用すると以下のようになる。

$$
\begin{aligned}
& \operatorname{rot} H=i+\frac{\partial D}{\partial t}-\cdots------(1) \\
& \operatorname{rot} E=-\frac{\partial B}{\partial t}---------(2) \\
& D=\varepsilon E-\cdots-\cdots-\cdots-\cdots-(3) \\
& B=\mu H-----------(4)
\end{aligned}
$$

さらに抵抗体に関して次式が適用される。

$$
i=\sigma E----\cdots---\cdots--(5)
$$

ここに，H:磁界の強さ $[\mathrm{A} / \mathrm{m}], i$ 抵抗分電流密度 $\left[\mathrm{A} / \mathrm{m}^{2}\right], D$ : 電 束密度 $\left[\mathrm{C} / \mathrm{m}^{2}\right], E:$ 電界 $[\mathrm{V} / \mathrm{m}], B$ 磁束密度 $[\mathrm{T}], \mu$ 透磁率 $[\mathrm{H} / \mathrm{m}]$, $\varepsilon$ :誘電率 $[\mathrm{F} / \mathrm{m}], \sigma=\sigma(\mathrm{i}, \mathrm{r}, \mathrm{t}):$ 導電率 $[\mathrm{S} / \mathrm{m}]$

（3）（4）（5）式を（1）式に代入し, rotationをとって

(2) 式を用いて変形すると次式が得られる。 


$$
\frac{1}{\mu} \operatorname{rot}(\operatorname{rot} B)=\operatorname{rot}(\sigma E)-\varepsilon \frac{\partial^{2} B}{\partial t^{2}}-\cdots
$$

以上の諸量は 3 次元空間でのベクトル量であるが, 酸化亜 鉛素子は一般に円板形状をしているので, 円筒座標系を採用 し，その成分を以下のように考慮する。 $B=\left(B_{r} B\right.$ $\left.{ }_{0}, B_{z}\right)=(0, B, 0)$ および $i=\left(i_{r}, i_{0}, i_{z}\right)=(0,0, i)$ 寸なわち，電流 密度はZ 方向 (円板高さ方向) 従って磁束密度は $\theta$ 方向成分 を考えて（6）式から順に解くと以下の式が得られる。

$$
\begin{aligned}
& B=\frac{1}{\mu s(\sigma+\varepsilon s)}\left(\frac{\partial^{2} B}{\partial r^{2}}+\frac{1}{r} \frac{\partial B}{\partial r}-\frac{B}{r^{2}}-\mu \frac{i}{\sigma} \frac{\partial \sigma}{\partial r}\right) \\
& ---(7) \\
& i=\frac{1}{\mu\left(1+\varepsilon(1 / \sigma)+\frac{\varepsilon}{\sigma} s\right)}\left(\frac{\partial B}{\partial r}+\frac{B}{r}\right)-\cdots-(8) \\
& i c=\frac{\partial D}{\partial t}=\varepsilon \frac{\partial(i / \sigma)}{\partial t}-\cdots---(9)
\end{aligned}
$$

ここに, $r: \mathrm{ZnO}$ 素子の半径方向の位置, $i c ：$ 変位電流密 度（容量分電流密度しいう）, s: $/ \partial / \partial \mathrm{t}$

（7）（8）（9）式はrに関する偏微分の式であるが, 差分 法を適用して，また心に関してはラプラス変換法を用いて逐 次計算機により, 計算時間刻み毎に諸量の侹を求めることが

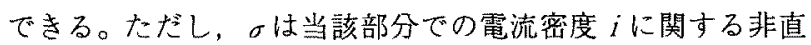

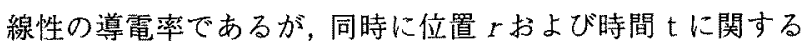
関数でもある。(7) 式の右辺を 1 時刻前の量で近似し, 差 分法で各時刻毎に各部の磁束密度 $B$ 求め, その結果を(8) 式に代入して抵抗分電流密度 $i$ 求める。さらにその結果を （9）式に代入して容量分電流密度icが求められる。 酸化亜鉛素子の半断面棈造を図 1 に示した。半径 $r_{m}$ を等

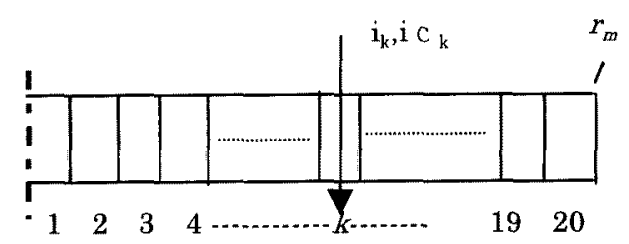

図1 $\mathrm{ZnO}$ 素子の半断面構造

Fig.1. A half section of $\mathrm{ZnO}$.

しく20 分割した区分を考え，その内側から $\mathrm{k}$ 番目の区分 に流れる抵抗分電流，容量分電流をそれぞれ $i_{k} ， i c_{k}$ とする。 またこの区分での紙面に垂直方向の磁束密度を $B_{k}$ とし，注 入電流の周波数に応した時間刻み毎に各区分での $B_{k}, i_{k}$, $i c_{k}$ の值を求めた。実際に使用したソフトは EMT Pプログ ラムの Modelsにより行った。

解析時に使用したデー夕の值を表 1 と図 2 に示した。尊電

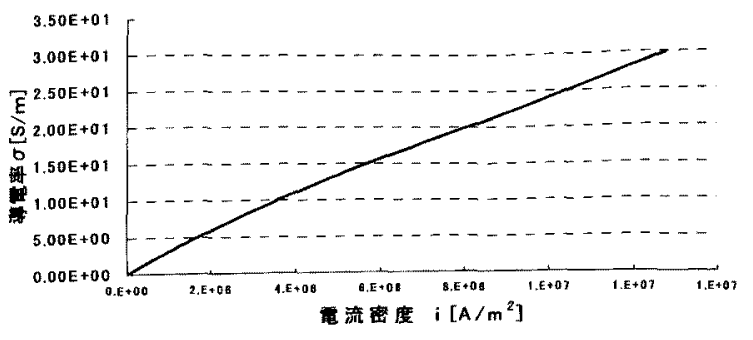

図2 非直線性の導電率

Fig.2. Non-linear conductivity $\sigma$.

率は直線抵抗に対応する一定値の場合と非直線抵抗に対応 する図 2 の場合の両者を, また誘電率は実測値の 500 を主体 とした。高周波での誘電率の低下も考えられるので 250 お び $100 の$ 場合も検討したが, 容量分電流がその分減少する他 は大差ないので, 紙面の都合場割愛した。注入電流の波高值

\begin{tabular}{|c|c|c|}
\hline \multicolumn{2}{|c|}{ 項目 } & 数 \\
\hline \multicolumn{2}{|c|}{$\mathrm{ZnO}$ の半径: $r_{m}$} & $0.05[\mathrm{~m}]$ \\
\hline \multirow{2}{*}{$\begin{array}{l}\text { 導電率： } \\
\sigma\end{array}$} & 直線抵抗 & $3.907[\mathrm{~S} / \mathrm{m}]$ \\
\hline & 非直線抵抗 & 図 2 参照 \\
\hline \multicolumn{2}{|c|}{ 比誘電率 $: \varepsilon_{s}$} & $\varepsilon_{\mathrm{s}}: 500$ \\
\hline \multicolumn{2}{|c|}{$\begin{array}{l}\text { 注入電流 (波高值と周 } \\
\text { 波数) }\end{array}$} & $\begin{array}{l}I_{m}{ }^{*} \sin (2 \pi \mathrm{ft}) \\
I_{m}: 10,000[\mathrm{~A}] \\
f: \text { (a) } 2.5 \mathrm{MHz} \\
\text { (b) } 25 \mathrm{MHz} \\
\text { (c) } 250 \mathrm{MHz}\end{array}$ \\
\hline
\end{tabular}
は公称放電電流の $10,000[\mathrm{~A}]$ とし, 周波数を $2.5,25,250 \mathrm{MHz}$ など変化させた。

表 1 解析に用いたデータ

Table 1. Data in analysis.

く2.2> 理論式による解析結果 前記の各条件で解

\begin{tabular}{|c|c|c|c|c|}
\hline \multirow[t]{2}{*}{ 図番 } & \multicolumn{2}{|c|}{ 導電率 $\sigma$} & \multirow[t]{2}{*}{ 比誘電率 $\varepsilon_{s}$} & \multirow{2}{*}{$\begin{array}{l}\text { 電流の周 } \\
\text { 波 数 } f \\
(\mathrm{MHz})\end{array}$} \\
\hline & $\begin{array}{l}\text { 非 直 } \\
\text { 線 }\end{array}$ & 直線 & & \\
\hline 3 & - & $\mathrm{O}$ & 500 & 250 \\
\hline 4 & 0 & - & 500 & 25 \\
\hline 5 & 0 & - & 500 & 250 \\
\hline
\end{tabular}
析した波形のうち代表的なものを以下に掲げた。各波形の図 と解析条件を対応させたものを表 2 に示した。

\section{表 2 波形図とその解析条件の対応}

Table 2. Figures and their analitical conditions.

周波数 $2.5 \mathrm{MHz}$ では周波数効果が殆ど見られなかった (ほぼ同じ電流密度) ので， $25 \mathrm{MHz}$ 以上の場合につき解 析し，電流密度波形を順に示した。抵抗分·容量分の電流 密度の両者とも比率 (最大電流 $10,000 \mathrm{~A}$ が均一に流れたと したときの密度に対する比）で表示した。また，図1の素 子半断面図で区分 $k(1 \sim 20)$ の ち $1,3,5,7,9,11,13,15,17,19,20$ 番目の 11 個の電流波形をグラ フで示したが，そのうち 1 と 20 番目の位置を知印で明 

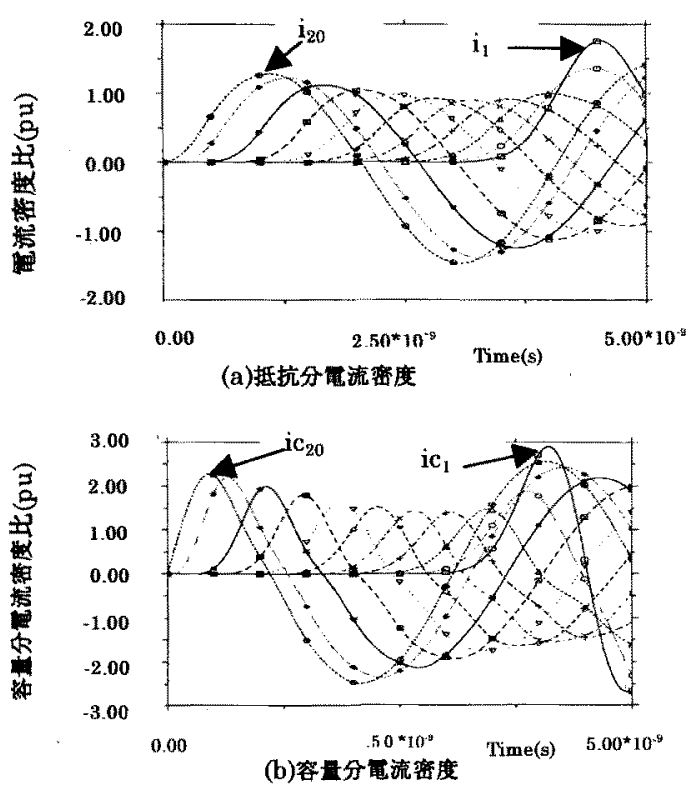

图 3 直線抵抗に対する電流密度波形 $(\varepsilon \dot{\varepsilon} ; 500, f$. $250 \mathrm{MHz}$ )

Fig.3. Waveshape of current density in linear resistance.
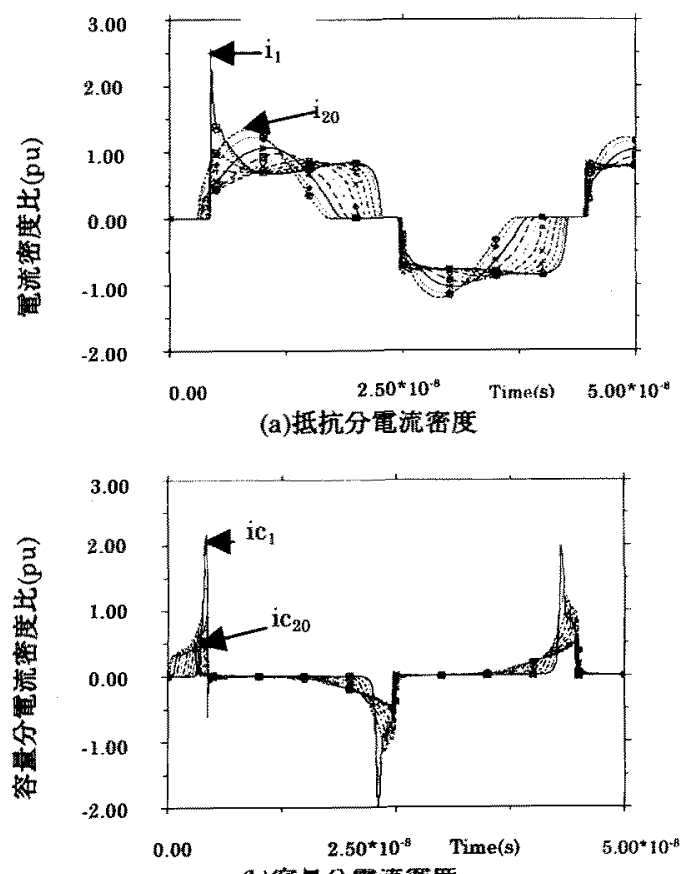

(b)容量分電流瑟度

図 4 非直楾抵抗に対する電流密度波形 $\left(\varepsilon_{s}: 500, f\right.$. $25 \mathrm{MHz}$ )

Fig.4. Waveshape of current density in nonlinear resistance.

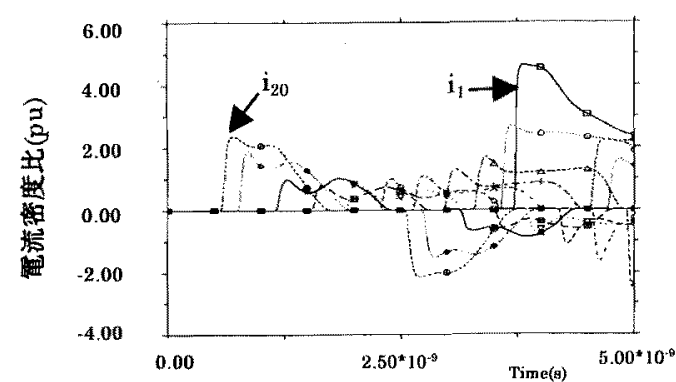

(a)抵抗分奄流密度

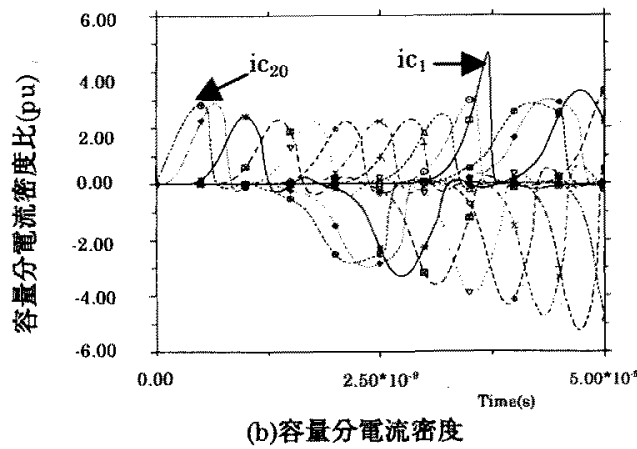

図 5 非直線抵抗に对する電流密度波形 $(\varepsilon ;$ $500, f .250 \mathrm{MHz})$

Fig.5. Waveshape of current density in non-linear resistance.

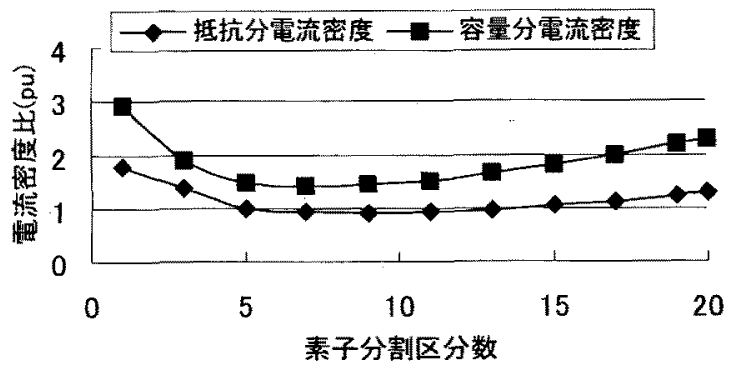

図6 理論解析による直線抵抗の電流波高值分 布(f:250MHz,es:500)

Fig.6. Theoretical current peak distribution on linearresistance $(f: 250 \mathrm{MHz}, e s: 500)$

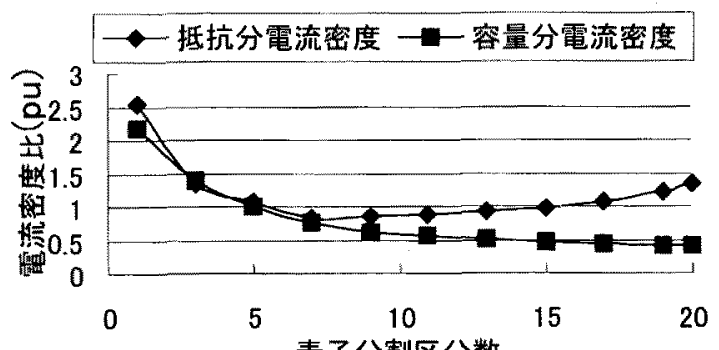

図7 理論解析による非直線抵抗の電流分布 (f.25MHz,es:500)

Fig.7. Theoretical current peak distribution on nonlinear-resistance (f.25MHz,es:500). 


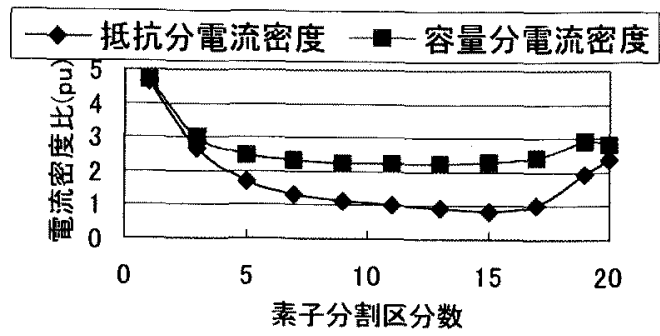

図8 理論解析による非直線抵抗電流波高 值分布(f.250MHz,es:500)

Fig.8. Theoretical current distribution on nonlinear-resistance(f:250MHz,es:500).

記し，他は省略したが，他の波形も図の順番に対応して いる。

また，図6，7，8にはそれぞれ図 3，4，5の電流波 高值の分布をまとめた結果を示している。これらの四から $10,000 \mathrm{~A} の$ 急峻波電流に対する電流分布に関して次の上う な結果が分かる。抵抗分電流拧よび容量分電流いずれに対 しても少なくも $25 \mathrm{MHz}$ 以上で周波数効果が発生した。笪 流の立ち上がり時間は外側電流（分割区分数の大きな位置 の電流）ほど早く, 内側の電流（分割区分数の小さな位置 の電流）ほど遅れる傾向にある。電流波高值に関しては内 側が大きく，次に外側の順に大きく，中間部の電流は小さ くなる傾向にある。一般に抵抗体に関しての表皮効果は外 側の電流が大きくなる現象であるが，酸化坐鉛素子は単な る抵抗体とは相違し，高い誘電率を有するので静電容量の 効果も周波数の增加とともに表れ，いわゆる送電線路でみ られるフェランチ効果も同時に存在し，内側電流が增加す るものと考えられる。これは次の章の等価回路加らも容易 に考充られる。また，容量分電流の位相は抵抗分電流より 進んでいる傾向がみられる。図 3 の直線抵抗の場合には再 者の電流が連続的な波形を示す一方，図 $4 ， 5$ の非直線抵 抗では，容量分電流は，より断続的な波形を示す。図 4 の $25 \mathrm{MHz}$ の周波数の場合には容量分電流加抵抗分電流 への移行時に大きさスパイク状の電流が内側電流にみられ る。

\section{3. 等価回路による検討}

提案する等価回路を図 9 に示した。これは図 1 に断面図 を示したように，円板状の素子をリング形状の 20 個のブ ロックに分割し，各ブロックはその断面積に応じて決まる 非直線抵抗と静電容量の並列接続で構成し, 各ブロック間 に所定のインダクタンスで接続した回路の外部端に電流源 を設置した回路である。ブロック間のインダクタンスの值 は図1の断面図でブロック間に存在する磁束によるインダ クタンスの值を採用した。従って最も内側のブロック1で はブロック 2 より外側に存在するすべての磁束と鎖交すた ため最も大きなインダクタンスを有し, 図 9 の等価回路で は 20 個のインダクタンスを介して電流源に接続される。
L

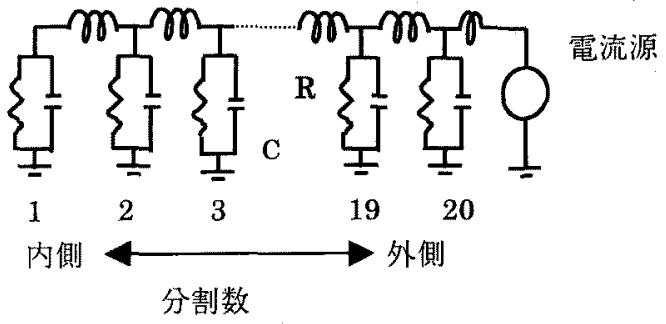

図 9 提案した等価回路

Fig.9. Proposed equivalent circuit .

ここに，R,C,Lの值を左から顳に以下に示す。 $\mathrm{R}$ ：非直線抵を $7.2 \mathrm{kV}$ での電流(A)で表示すると $25,75,125,175,225,275,325,375,425,475$, $525,575,625,675,725,775,825,875,925,975$ L:インダタタンスを $(\mathrm{H})$ 単位で表示すると $\left(10^{-10}\right)$ $48.3,22.5,14.9,11.1,8.83,7.35,6.29,5.51,4.89$ ,4.40,4.00,3.67,3.39,3.14,2.93,2.75,2.59, $2.45,2.32,1.11$

$\mathrm{C}:$ キャパシタンスを（pF）単位で表示すると $3.95,11.9,19.8,27.7,35.6,43.5,51.5$, $59.5,67.0,75.0,83.0,91.0,99.0,106.5$, $114.5,122.0,130.5,138.5,146.0,154.0$

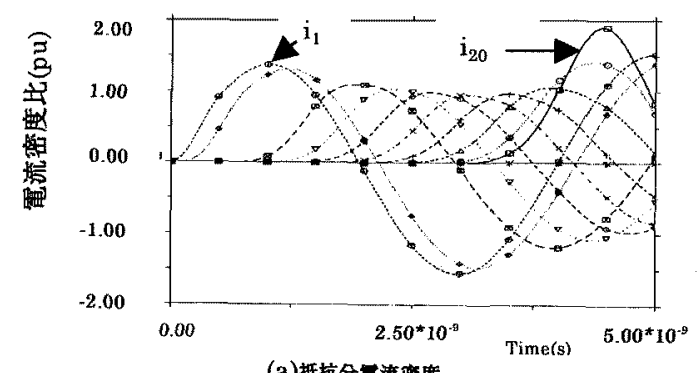
(a)拱抗分地流察度

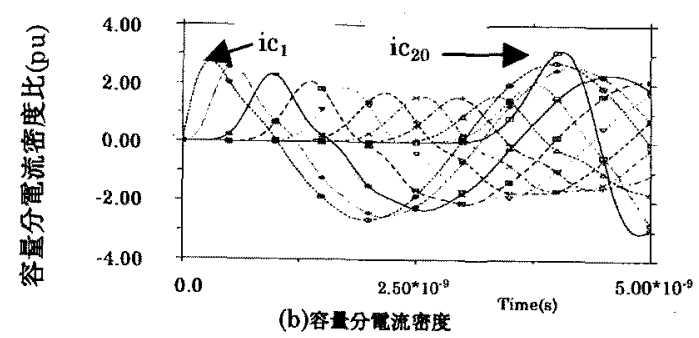

図 10 等価回路での直楾抵抗に対する電流密 度波形 $\left(\epsilon_{s} ; 500, f .250 \mathrm{MHz}\right)$

Fig.10. Waveshape of current density in non-linear resistance by equivqlent method.

大きなブロック数の外側ブロック程, 鎖交磁束数が減少し， 従って当該ブロックから電流源までのインダクタンスの值 が減少することを意味している。

この等価回路を用いて第 2 章で検討したと同じ条件で 


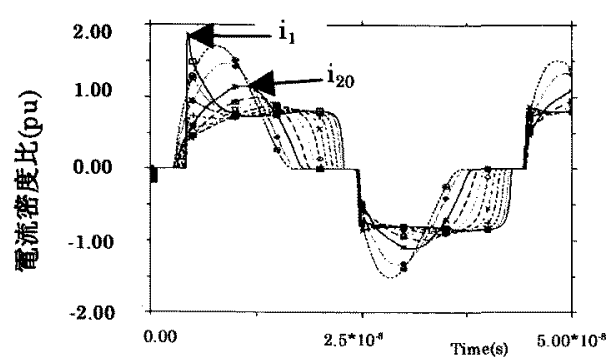

(a)抵抗分電流密度

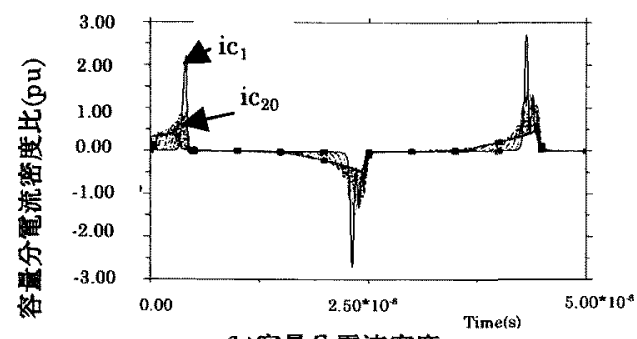

(b)容量分電流密度

図 11 等価回路での非直線抵抗に対する電流密 度波形 $\left(\varepsilon_{s}: \mathbf{5 0 0}, f .25 \mathrm{MHz}\right)$

Fig.11. Waveshape of current density in nonlinear̂ resistance by equivalent method
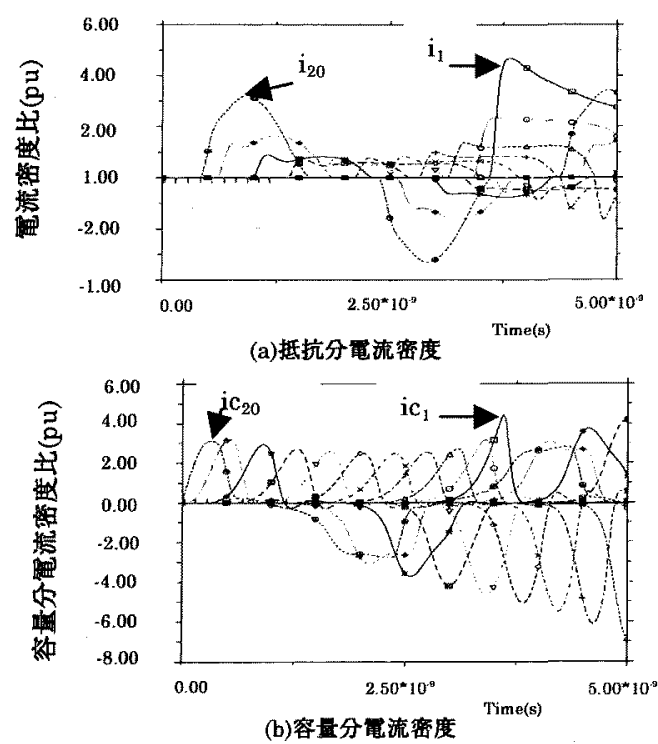

図12等価回路での非直楾抵抗に対する 電流密度波形 $\left(\epsilon_{s}: 500, f .250 \mathrm{MHz}\right)$

Fig.12. Waveshape of current density in non-linear resistance by equivqlent method.

解析を行った。第 2 章の理論解析の図 3 から 8 に対応する 等価回路での解析結果をそれぞれ図10から 15 に示しだ。 応する電流密度比率の波形およびその波高值はいずれもよ く一致して扔り，提案した等価回路が妥当であることが分 かる。

図 9 の酸化要鉛素子の等価回路は通常の EMTP などによ

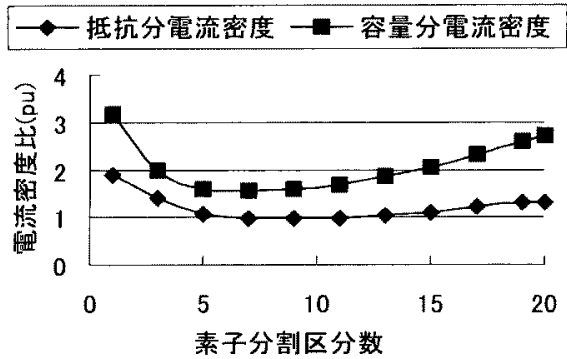

图13 等洒回路法による直線抵抗の電流波 高值分布( ( .250MHz,es:500)

Fig.13. Peak current distribution by equivalent circuit on linear-resistance (f.250MHz,es:500).

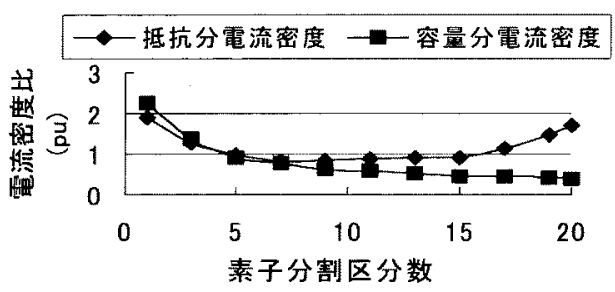

図 14 等価回路法による非直線抵抗の

電流波高值分布(f:25MHz,es:500)

Fig. 14. Peak current distribution by equivalent circuit on non-liner resistance $(\mathrm{f}: 250 \mathrm{MHz}, \mathrm{es}: 500)$

\section{一抵抗分電流密度 一- 容量分電流密度}

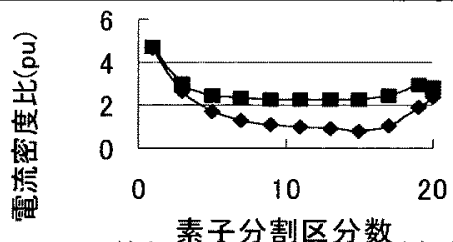

図15 等価音甾分割区分数線抵抗の波 高値分布 (f:250MHz,es:500)

Fig.15. Peak current distribution by equivalent circuit on non-linear resistance (f:250MHz,es:500)

る解析に便利なモデルであり，一般の回路の中に入れて諸 種の評価が可能である。

4. 応用例

<4. $1>$ 臨界周波数の検討 今までの調查では表 1 に 示すように電流值を公称放電電流の $10,000 \mathrm{~A} に$ に固定し, 周 波数も $2.5,25,250 \mathrm{MHz}$ と大きく変化させて周波数特性を検 討してきた。ここでは電流值を放電耐量の領域まで拡大し, $10,000 \mathrm{~A}$ から $100,000 \mathrm{~A}$ まで変化させ, 周波数も $500 \mathrm{kHz}$ 扣よび $1,2.5,5,10,15,25 \mathrm{MHz}$ と細かく変化させて非直線 抵抗体である酸化业鉛素子の周波数効果が表れ始める臨界 周波数を求めた。前章で述べた等価回路手法により求めた。 一般に電流周波数を上げると，ある周波数から内部電流の 位相のずれおよび大きさの不均一が発生するが, 少なくと もいずれか一方の現象が始まる周波数の下限值を臨海周波 数と定義した。

図 16 は電流值と臨界周波数との関倸を求めた結果を示す。 
図のように電流值を増加すると臨界周波数は約 $5 \mathrm{MHz}$ 絮 ら $1 \mathrm{MHz}$ に低下している。電流を増加させると非直線抵抗 の抵抗值が小さくなり，周波数効果を表れ易くなることを 示している。

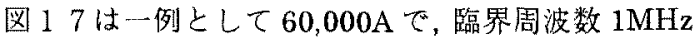
における素子の内部の抵抗電流分布を示した。各部電流 が異なり始め，内部電流の周波数效果が表れ初めている ことが分が。

<4. $2>$ 端子電压波形の検討 今までの調查では 素子内部の電流の周波数效果による分布を検討してきた が，図 9 に示した等価回路法では電流源のところの端子 電圧が素子全体の当該電流における端子電圧になる。図 9 の等価回路モデルで解析した電圧波形と従来一般に使 用されている非直線抵抗体での解析による端子電生波形 と比較検討を行った。提案の等価回路法では素子を誘電 体と考え, 静電容量付きである⿸尸口で, 従来法でも非直線 抵抗と静電容量の主列接続として扱った。徒来法の非直 線抵抗は図 2 の導電率曲線に対応する電圧一笔流特性を EMTP の 92 番のモデルで模擬した。比較検討の条件は 電流做が $10,000 \mathrm{~A}$ で周波数 $25 \mathrm{MHz}$ の正弦波電流を素子 に注入をる条件とした。等価回路法と従来法での端子電 圧波形をそれぞれ，図18，19に示した。

等価回路法では従来法に比べ，波高值が数パーセント高 く,かつ波高值を過ざた後の電圧波形の下がりが大きく ，いわゆとヒステリシス特性を有している。また，图示 していないが， $25 \mathrm{MHz}$ よりも高い周波数では周波数特 性が一層表れ易くなるので，等洒回路法と従来法の波形 の差はますます増大する方南であった。

図 20 は電流值 $10,000 \mathrm{~A}$ で周波数 2.5 扔よび $25 \mathrm{MHz}$ 対する電圧一電流特性のヒスデリシス曲線を等価回路法 により求めた結果を示し，周波数が上がる程，静電容量 性に移行する傾向が分かる。

従来，素子の電压一電流がとステリシス特性を示した り，急峻波電流で電压值が上昇するのは素子の物性によ るものと理解されてきたが，電気回路上の理由でも同様 な現象が表れることが分かった。

\section{5.むすび}

本論文で述べたところを要約すると以下のようになる。 (1) 非直線抵抗体である酸化垔鉛素子を誘電体と考え て各種周波数の電流に対する内部電流分布を理諭的に求め る方法を明らかにした。

(2) 上記の理論的な万法と同样な結果を与える電気的 等価回路手法を提案した。

（3）上記等洒回路手法を用いて周波数特性が顕著に表 れ始的る踄界周波数を明らか心した。

（4）上記等価回路手法を用いて素子の端子電压波形が 求められることを示し，従来法と比較した。

以上のように本研究は酸化亜鉛素子の周波数特性に関し て理論面から応答を求める手法を主体に検討したものであ
るが，将来さらに物性に関する実験的成果が明らかになれ
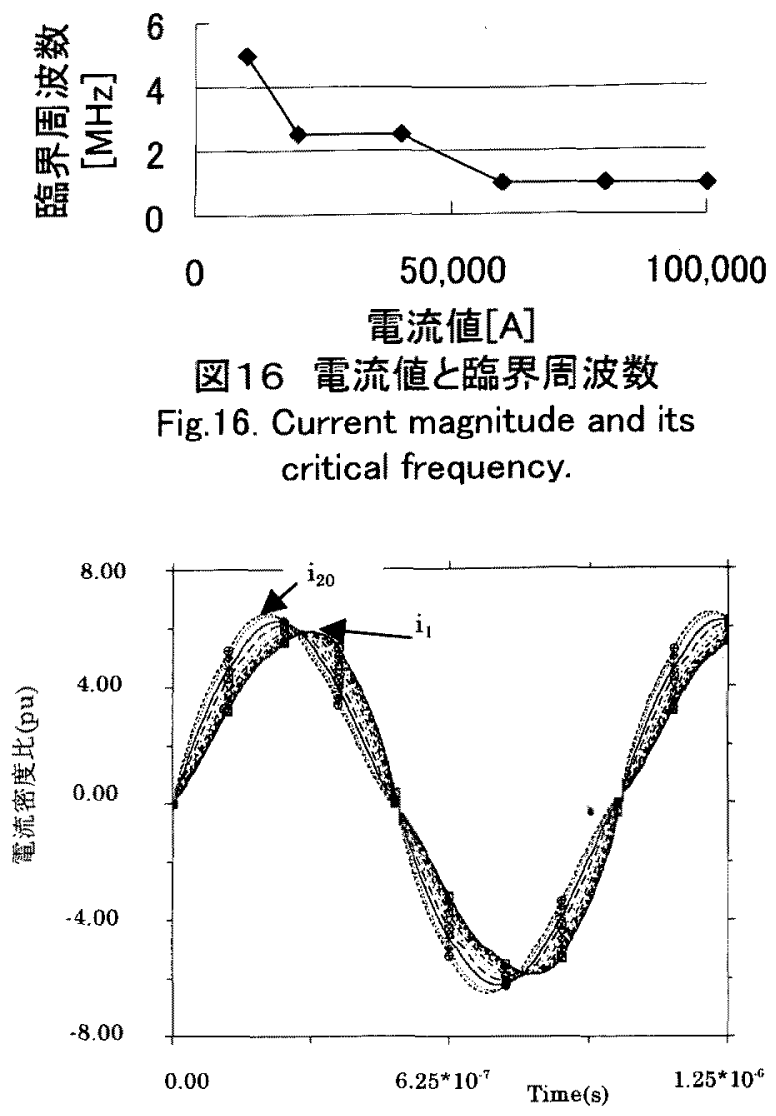

図 17 非直線抵抗の臨界周波数『の電流密度波形 (全電流:60,000A, $\varepsilon_{s}: 500, f .1 \mathrm{MHz}$ )

Fig.17. Critical frequency waveshape of current density in non-linear resistance(total current: $60,000 \mathrm{~A}, \epsilon_{s}: 500, f .1 \mathrm{MHz}$ ).

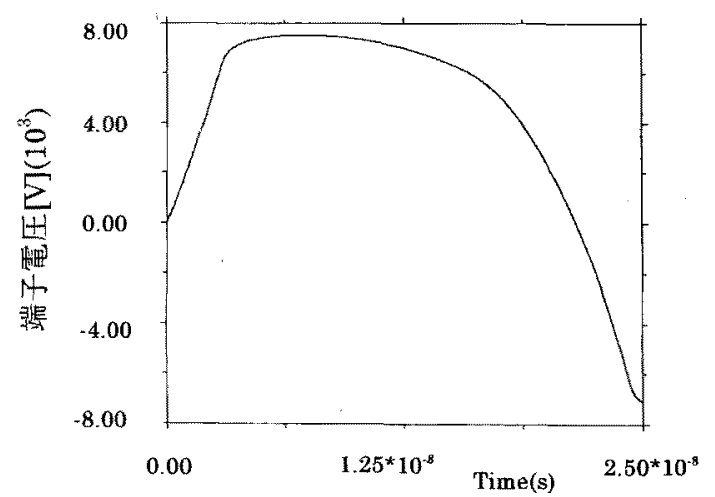

図 18 等価回路法で求めた端子電 压波形( $\mathrm{I}=10,000 \mathrm{~A}, \mathrm{f}: 25 \mathrm{MHz}, \mathrm{es}: 500)$

Fig.18. Terminal voltage of an element by equivalent method. 


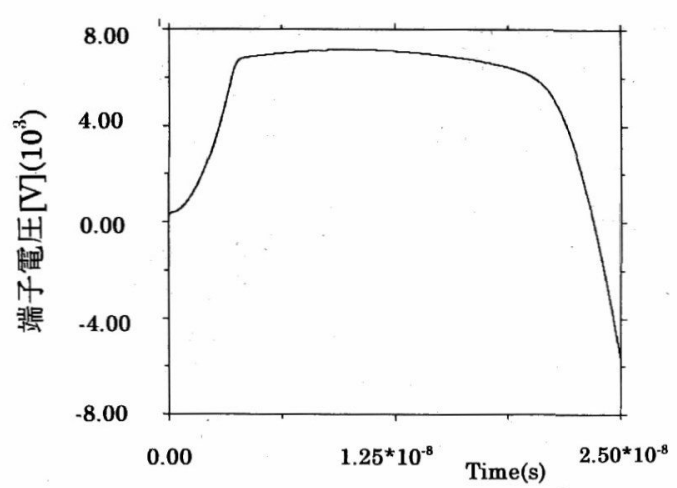

図 19 従来法による端子電圧波形 (I=10,000A,f:25MHz,es:500)

Fig.19. Terminal voltage of an element by conventional method.

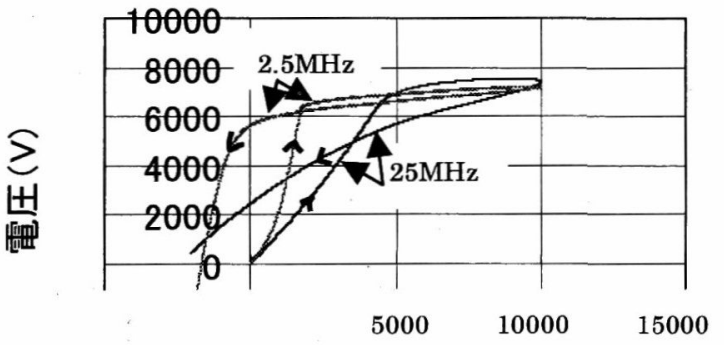

電流 $(A)$

図20 電圧·電流のヒステリシス曲線 Fig.20. V-I hysterisisi curve.

ば, 本研究成果と組み合わせることにより，一層の発展が 期待される。

なお本研究に対してご支援頂いた（株）東芝，また，卒 業研究として本研究の一部に従事された横溝充, 澤和之, 斉藤敦の諸君に謝意を表します。

(平成 11 年 11 月 26 日受付, 平成 12 年 02 月 07 再受付) 文献

(1) IEEE Working Group 3.4.11: "Modeling of Metal Oxide Surge Arresters",IEEE Trans.Power Delivery,PWRD-7,1(Jan.1992)

(2) 電気学会技術報告第 566 号：「変電所統計絶 縁設計のための雷サージ評価手法」，33～38, (1995-10)

（3）小島宗次・菅雅弘・舛沢弘一：「酸化亜鉛形避 雷器のエネルギー依存モデル」, 電学論. $B, 114$ 巻 3 号, 310 316(1994-3)

（4）速水英紀・山本秀信他：「酸化亚鉛素子の表皮 効果に関する研究」, 平成 7 年電気学会電力・エネルギー 部門大会, No.564

（5）横溝充 - 足立原一美 - 小島宗次 ·河野照哉：「酸
化亜鉛素子の内部電流分布に関する研究」,平成 10 年電 気学会全国大会, No.1534, (1998-3)

(6) Soji Kojima:"Theoretical Method for Internal Current Distribution to Very Fast Transient Current on a ZnO element”, 開閉保護 - 高電圧合同研究会資料, SP-99-26/HV-99-26, (1999-1)

（7）小島宗次・澤和之 ·斉藤敦 - 河野照哉・錦織康 男 :「酸化亜鉛素子に対する等価回路の考察」, 平成 1.1 年電気学会全国大会, No.1546, (1999-3)

(8) Soji Kojima,Teruya Kouno, Yasuo Nishikori: "Skin and Ferranti Effects of $\mathrm{ZnO}$ Internal Current to Very Fast Transient Current", $11^{\text {th }}$ ISH99, 2.321P(1999-8)

小島宗次 (正員) 1939 年 3 月 30 日生まれ。

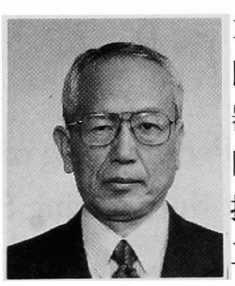
1963 年 3 月東京大学電気工学科卒業。 同年 4 月(株)東芝入社。浜川崎工場避雷 器部に所属。1997 年 3 月退社し, 同年 4 月より工学院大学電気工学科教 授, 現在に至る。電力システム工学担当。 工学博士。耐雷素子および絶縁協調の研 究に従事。電気学会進歩賞·論文賞受賞。 IEEE 会員。

江頭 健太郎 (学生員)1997 年 1 月 22 日生まれ。

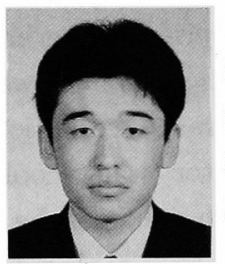
1999 年 3 月工学院大学工学部電気工学 科卒業。同年 4 月同大学大学院工学研 究科電気·電子工学専攻修士課程に入学, 現在に至る。主に酸化要鉛素子の急峻波 応答に関する研究に従事。

河野 照哉 （正員）1934 年 6 月 21 日生まれ。

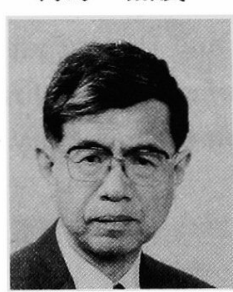
1962 年東京大学大学院数物系研究科修 了, 工学博士。1962 年 4 月より東京大 学工学部電気工学科に勤務。1995 年 3 月東京大学を定年退職, 同年 4 月より 工学院大学教授, 現在に至る。高電圧工 学担当。電気学会より論文賞, 著作賞, 電力賞を受賞。1980, 1981 年度電気学 会編集理事。1988 年度東京支部長, 1991 年度 $A$ 部門長。

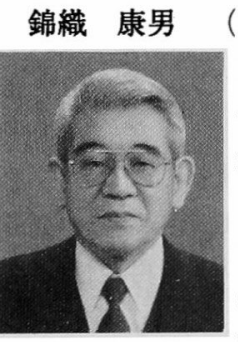

（正員） 1941 年 11 月 14 日生まれ。 1968 年 3 月工学院大学大学院修士課程 修了, 同年 4 月同大学電気工学科に勤 務。電子顕微鏡の応用研究に従事の後, 1986 年 4 月より気体放電現象およ び高電圧測定技術の研究に従事。電気工 学科講師。日本電子顕微鏡学会, 応用物 理学会, 静電気学会会員 